Geology, Geophysics \& Environment • 2012 • Vol. 38 • No. 1 • 35-49

http://dx.doi.org/10.7494/geol.2012.38.1.35

\title{
TARAS WODNY GÓR WSCHODNICH - NAJSTARSZY WYCIEK W KOPALNI SOLI ,WIELICZKA”
}

\author{
Taras Wodny Gór Wschodnich - \\ the oldest inflow in the Wieliczka Salt Mine
}

Kajetan d'OBYRN ${ }^{1,2}$ \& Jadwiga STECKA ${ }^{1}$

\author{
${ }^{1}$ Kopalnia Soli „Wieliczka” SA; Park Kingi 1, 32-020 Wieliczka \\ ${ }^{2}$ Politechnika Krakowska; ul. Warszawska 24, 31-155 Kraków; \\ e-mail: kajetan.dobyrn@kopalnia.pl, jadwiga.stecka@kopalnia.pl,
}

\begin{abstract}
Treść: Wycieki WI-36 i WI-37 występujące w wyrobisku Taras Wodny Gór Wschodnich są najstarszymi z dostępnych i kontrolowanych wycieków w Kopalni Soli „Wieliczka”. Należą też do grupy najważniejszych wycieków z uwagi na bardzo niską zawartość $\mathrm{NaCl}$ w dopływającej wodzie, jak również na ich lokalizację - ich końcówki naruszyły północną granicę złoża, odsłaniając utwory należące do warstw chodenickich, z którymi związane były wszystkie dotychczasowe katastrofy wodne w kopalni. Historia obecnych wycieków WI-36 i WI-37 sięga 1620 roku. Wielkość dopływu, analiza składu chemicznego i izotopowego dopływającej solanki wskazuje na różne systemy wodonośne zasilające te wycieki, jak również różne drogi przepływu wód.
\end{abstract}

Słowa kluczowe: miocen, złoże soli kamiennej Wieliczka, zagrożenie wodne, wyciek kopalniany

\begin{abstract}
Inflows WI-36 and WI-37 occurring in the excavation Taras Wodny Gór Wschodnich are the oldest accessible and controlled inflows into the Wieliczka Salt Mine. Due to low $\mathrm{NaCl}$ content as well as their location these inflows are considered as the most significant ones - their extremities have violated the northern border of the deposit, exposing at the same time the Chodenice beds, which have contributed to all water catastrophes in the mine so far. History of current inflows WI-36 and WI-37 dates back to 1620 . The volume of the inflow, the analysis of the chemical and isotopic composition of the inflowing brine indicates the existence of various water-bearing system supplying these inflows and also different routes of water flow.
\end{abstract}

Key words: Miocene, Wieliczka salt deposits, water hazard, water inflow 
Taras Wodny Gór Wschodnich to obecna nazwa wyrobisk położonych na pierwszym poziomie Kopalni Soli „Wieliczka”, w jego północno-wschodniej części. Są to dwa chodniki górny i dolny - wykonane po wzniosie w kierunku północnym, w których zarejestrowane są wycieki WI-36 i WI-37. Wycieki te są skutkiem ujęcia wód poza granicą złoża. Z uwagi na bardzo niską zawartość $\mathrm{NaCl}$ w dopływie należą do grupy najważniejszych zjawisk hydrogeologicznych oraz są najstarszymi z dostępnych i kontrolowanych wycieków w kopalni.

Wielickie złoże soli kamiennej jest częścią mioceńskiej formacji solonośnej, zalega równoleżnikowym pasem wzdłuż brzegu Karpat. Cechą wyróżniającą je od innych złóż solnych jest jego budowa geologiczna. Zbudowane jest z dwóch kontrastowo różniących się partii - dolnej pokładowej oraz górnej bryłowej. Złoże pokładowe to warstwy soli kamiennej poprzedzielane przerostami skał płonnych typu iłowców anhydrytowych. Złoże bryłowe budują skały płonne, głównie iłowce margliste i Zubry, wśród których tkwią różnej wielkości bloki soli kamiennej.

Północną granicę złoża i częściowo nadkład budują utwory warstw chodenickich i z nimi wiąże się największe zagrożenie dla kopalni - zagrożenie wodne. Południową granicę złoża wyznacza zasięg Karpat fliszowych. Spąg złoża stanowią utwory należące do warstw skawińskich. Całość przykrywają utwory czwartorzędowe. Złoże od wodonośnych warstw chodenickich oddziela wtórnie wykształcona otulina iłowo-gipsowa. Z warstw chodenickich pochodzi największe zagrożenie wodne dla kopalni i z nimi związane są największe i najgroźniejsze wycieki w kopalni, takie jak wyciek w komorze Fornalska 2 na poziomie VII, wyciek pod komorą Z-32 i z komory Z-28 na poz. VI. Dopływ do tych trzech wycieków stanowi $85 \%$ całkowitego dopływu do kopalni.

$\mathrm{Z}$ warstwami tymi związane były także wszystkie dotychczasowe katastrofy wodne. Szczęśliwie dla kopalni w warstwach chodenickich nie występuje jeden ciągły i zasobny system wodny, lecz wiele podsystemów, pomiędzy którymi połączenia hydrauliczne są bardzo utrudnione albo systemy te są wzajemnie odseparowane (Zuber \& Duliński 2004).

Poziom I, jako najbliższy powierzchni, wykonany został w większości w górnej, bryłowej części złoża. Chodniki Taras Wodny Gór Wschodnich górny i dolny poprowadzone zostały w skałach płonnych złoża bryłowego, a ich północne końcówki naruszyły północną granicę złoża - odsłonięte w nich zostały iłowce muliste z wkładkami twardych margli dolomitycznych należące do warstw chodenickich (Jaworski et al. 1984).

Zawodnienie poziomu I jest wynikiem wielu czynników. Poza typowymi drogami migracji wód do kopalni, jakimi są wyrobiska pionowe dochodzące do powierzchni (szyby, otwory wiertnicze) czy też naruszenie wyrobiskami północnej granicy złoża, migracja wód na poziom I następuje poprzez zruszony górotwór w wyniku zapadlisk dopowierzchniowych komór. W przeszłości kopalni zanotowano 22 przypadki zawalenia się komór dochodzących do powierzchni terenu. W wyniku tych zawałów powstały na powierzchni dużych rozmiarów zapadliska, a poprzez spękania i szczeliny zruszonego górotworu do kopalni zwykle przedostawała się woda czwartorzędowa (Kolasa \& Kubik 1983).

Obecnie na poziomie I zarejestrowanych jest 30 wycieków, które charakteryzują się niewielkimi wydatkami, w dużej mierze są wykropleniami ze stropu wyrobisk. Wielkością dopływu mniejszą niż $0.1 \mathrm{dm}^{3} /$ min charakteryzują się 23 wycieki, sześć wycieków ma wiel- 
kość dopływu zawierającą się w przedziale $0.1-1.0 \mathrm{dm} 3 / \mathrm{min}$, a wielkość wypływu mieszczącą się w przedziale $1.0-10.0 \mathrm{dm}^{3} / \mathrm{min}$ ma tylko jeden wyciek - WI-36. Wielkość dopływu na poziomie I to około $1 \%$ całego dopływu do kopalni (Bilans wycieków...).

Podsystem, z którego zasilane są wycieki WI-36 i WI-37, nie jest bardzo zasobny. Potwierdzają to badania przeprowadzone w otworze hydrogeologicznym H-11, który odwiercony został w roku 1985 w odległości ok. 100 m na północny wschód od końcówek chodników Taras Wodny Gór Wschodnich (Fig. 1). W miejscu odwierconego otworu H-11 stwierdzono obecność utworów chodenickich w przedziale wysokości 253.2-188.2 m n.p.m. wykształconych w postaci ciemnopopielatych iłowców z lokalnymi wkładkami mułków. Na podstawie przeprowadzonych w otworze badań hydrogeologicznych stwierdzono w przedziale wysokości 247.2-149.2 m n.p.m. występowanie wód podziemnych o napiętym zwierciadle wody i wydatku $0.66 \mathrm{~m}^{3} / \mathrm{h}, \mathrm{tj} .11 \mathrm{dm}^{3} / \mathrm{min}$ (Zimny 1985 ).

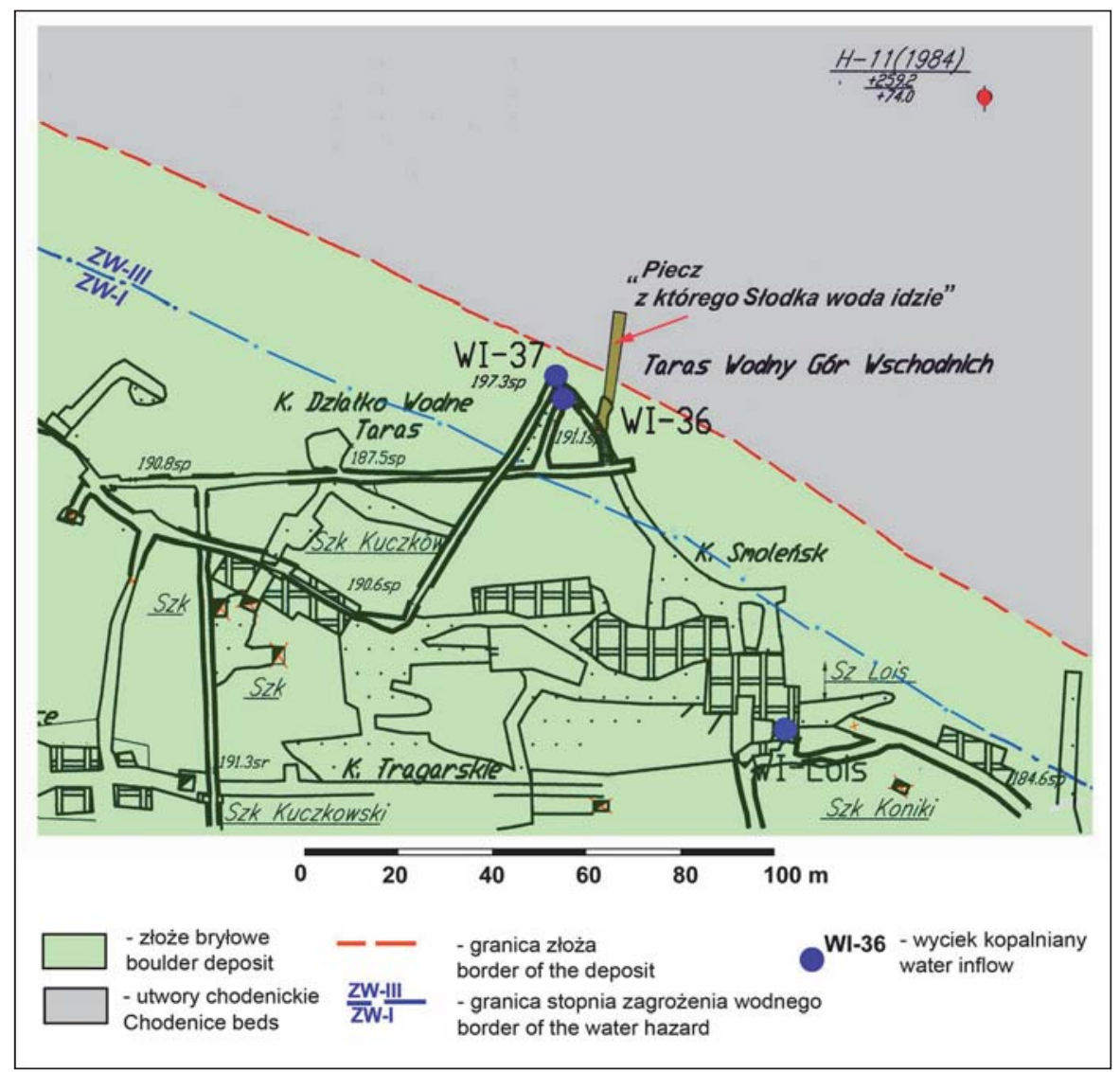

Fig. 1. Fragment mapy geologicznej poziomu I (Manterys 1980, zaktualizowała Stecka 2010)

Fig. 1. Fragment of the geological map of Level I (Manterys 1980, updated Stecka 2010) 
Pierwsze informacje o dopływającej słodkiej wodzie do rejonu występowania obecnych wycieków WI-36 i WI-37 pochodzą z roku 1622, kiedy to rozważano problem odwadniania tego rejonu w związku z uaktywnieniem się źródła słodkiej wody w granicznej strefie złoża (Jaworski et al. 1984). Dowodem istnienia tu wycieku jest też mapa wielickiego geometry Marcina Germana z roku 1638 roku Delineatio Prima Salisfodinae Wielicensis. Wizerunek Żupy Wielickey pierwszey, na której nieistniejący już dzisiaj chodnik został opisany jako „Piecz, z którego woda Słodka idzie” (d’Obyrn \& Przybyło 2010) (Fig. 2).

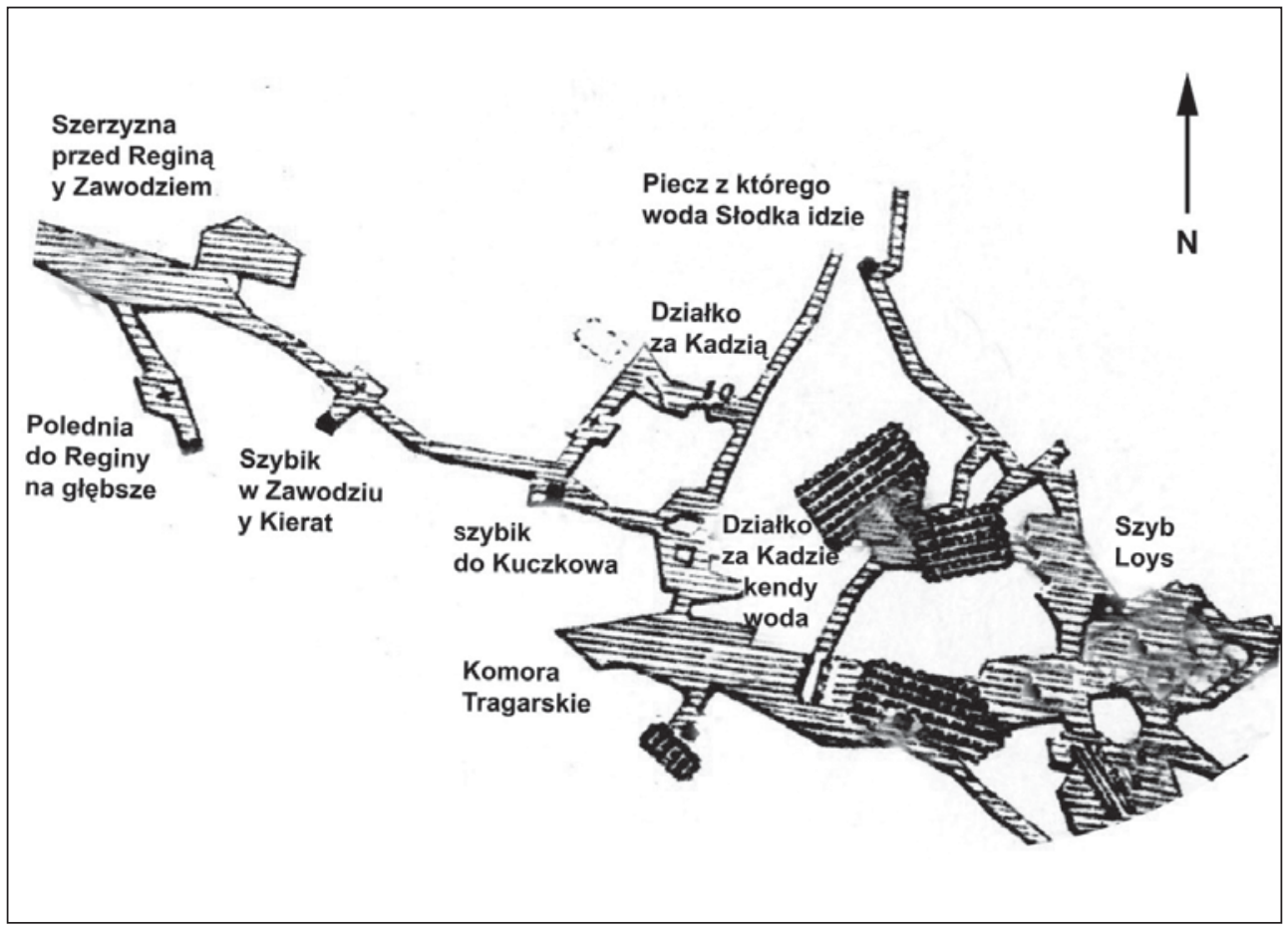

Fig. 2. Fragment mapy Marcina Germana Delineatio Prima Salisfodinae Wieliciensis. Wizerunek Żupy Wielickey Pierwszey, 1638

Fig. 2. Fragment of the map of Marcin German Delineatio Prima Salisfodinae Wieliciensis. Wizerunek Żupy Wielickey Pierwszey, 1638

Informacja na temat wycieku wody w rejonie wyrobisk Taras Wodny Gór Wschodnich znajduje się także w dokumentach lustracji królewskiej z roku 1642 przy okazji rozważania problemu odwadniania tego rejonu oraz w dokumentach lustracji z roku 1685, kiedy to remontowana była zniszczona obudowa chodnika prowadzącego do wycieku (Jaworski et al. 1984). 
W początkowym okresie dopływającą tu słodką wodę gromadzono w pobliskich komorach Zakadzie i Zawodzie. Kiedy jednak doszło do wzmożonego dopływu słodkiej wody, zaczęto ją odprowadzać do szybiku Zawodzie, a stąd na powierzchnię do warzelni soli. W tym okresie wody z wycieku używano do picia i pojenia koni (Jaworski et al. 1984). W roku 1843 geolog Ludwik Zejszner w Krótkim opisie historycznym, geologicznym i górniczym Wieliczki zamieszcza opis tego miejsca: „To szczególne źródło wśród kopalni na pierwszym piętrze znajduje się w chodniku zwanym Na zawodziu w głębokości 168 stóp paryzkich. Wyborna ta woda do picia pospolicie jest chłodną, miała bowiem temperaturę w [dniu] 20 Czerwca 1839 r. $+9^{\circ} \mathrm{C}$. Godna jest to istotnie okoliczność zastanowienia, jakim sposobem słodka woda przechodzi przez warstwy należące do pokładu solnego, nie zetknąwszy się nigdzie ze solą. Źródła tego nie tylko górnicy, ale i konie za napój używają, w znacznej bowiem ilości ustawicznie dopływa" (Zejszner 1843).

Układ wyrobisk Taras Wodny Gór Wschodnich jest niezwykle skomplikowany. Występuje tu sieć starych, powstałych w XVI i XVII wieku wyrobisk oraz nakładające się na nie wykonane w XIX wieku ciągi komunikacyjne. Skomplikowana i urozmaicona zarówno w pionie, jak i poziomie konfiguracja wyrobisk bardzo utrudnia prowadzenie tu prac górniczych (Fig. 3).

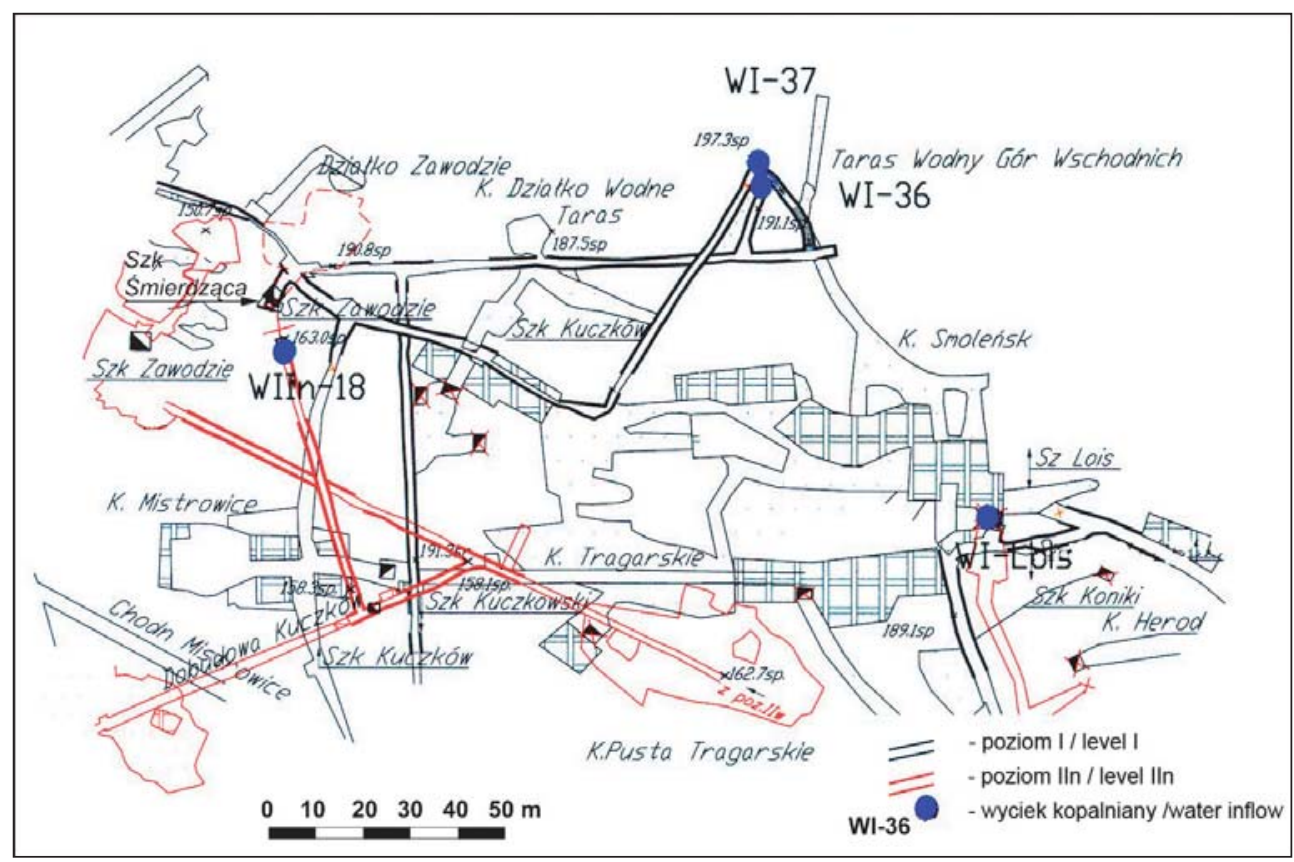

Fig. 3. Fragment mapy wyrobisk górniczych poziomów I i IIn w rejonie chodników Taras Wodny Gór Wschodnich

Fig. 3. Fragment of the mining excavation map of Levels I i IIn in the Taras Wodny Gór Wschodnich area 
Najstarszym wyrobiskiem w tym rejonie, wykonanym prawdopodobnie jeszcze przed 1518 r., jest chodnik biegnący od obecnego ujęcia wycieku WI-37 do szybiku Zawodzie. Obecne chodniki dojściowe do wycieków powstały w pierwszej połowie XIX w. (Jaworski et al. 1984).

W kolejnych latach wykonywane były tylko remonty ujęć wycieków. W roku 1964 przeprowadzony został doraźny remont ujęcia. Zabezpieczono wtedy chodniki wykonując pełną obudowę drewnianą. Czoło chodnika górnego zabezpieczono tamą murową, zaś w chodniku dolnym wybudowano tamę klocową, przed którą znajduje się próg wodny (Sękiewicz 1966). Remont w roku 1964 oraz później prowadzone doraźne prace nigdy nie doprowadziły do szczelnego ujęcia wycieku. Występowały i obecnie też występują przecieki poza ujęciem, które w sposób niekontrolowany przedostają się na niższe poziomy kopalni, ługując na drodze spływu występującą sól (Fig. 4). Przy obecnym stanie ujęć nie można określić w sposób precyzyjny wielkości dopływu do tego rejonu ani też wielkości ewentualnych przecieków.

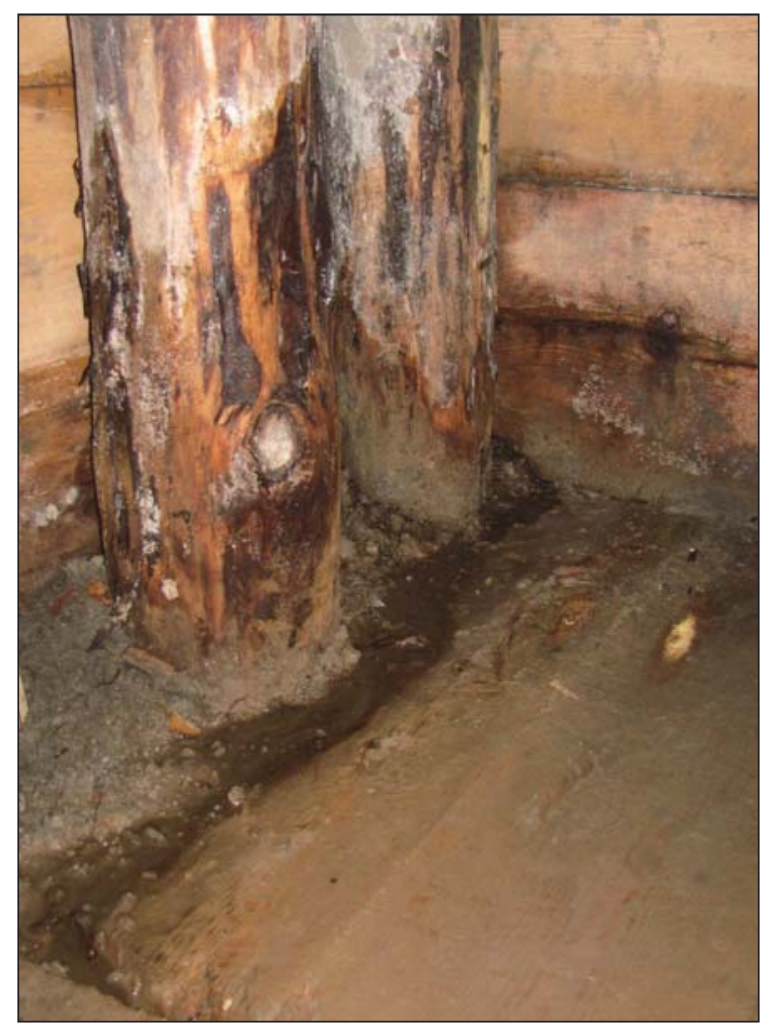

Fig. 4. Przecieki poza ujęcia wycieków WI-36 i WI-37 we wschodniej końcówce chodnika Taras Gór Wschodnich (fot. J. Przybyło 2010)

Fig. 4. Leakages in the eastern extremity of the Taras Gór Wschodnich galery beyond the WI-36 and WI-37 inflow intakes (phot. J. Przybyło 2010) 
W latach 1983-1993 z powodu niedrożnego chodnika nie było możliwości pomiaru wielkości dopływu do ujęcia wycieku w chodniku górnym.

W chwili obecnej wyciek ujęty jest w dwóch miejscach, tj. w czole chodnika dolnego i w czole chodnika górnego jako wycieki WI-36 (Fig. 5) i WI-37 (Fig. 6).

Rzędna spągu chodnika górnego w miejscu obecnego ujęcia wynosi 197.3 m n.p.m., a rzędna spągu dolnego chodnika wynosi 192.3 m n.p.m. Różnica wysokości obecnych ujęć wynosi zatem $5 \mathrm{~m}$. Ujęte w chodnikach górnym i dolnym wycieki spływają do metalowego rząpia zlokalizowanego u wlotu do chodnika dolnego, skąd odprowadzane są do systemu odwadniania kopalni.

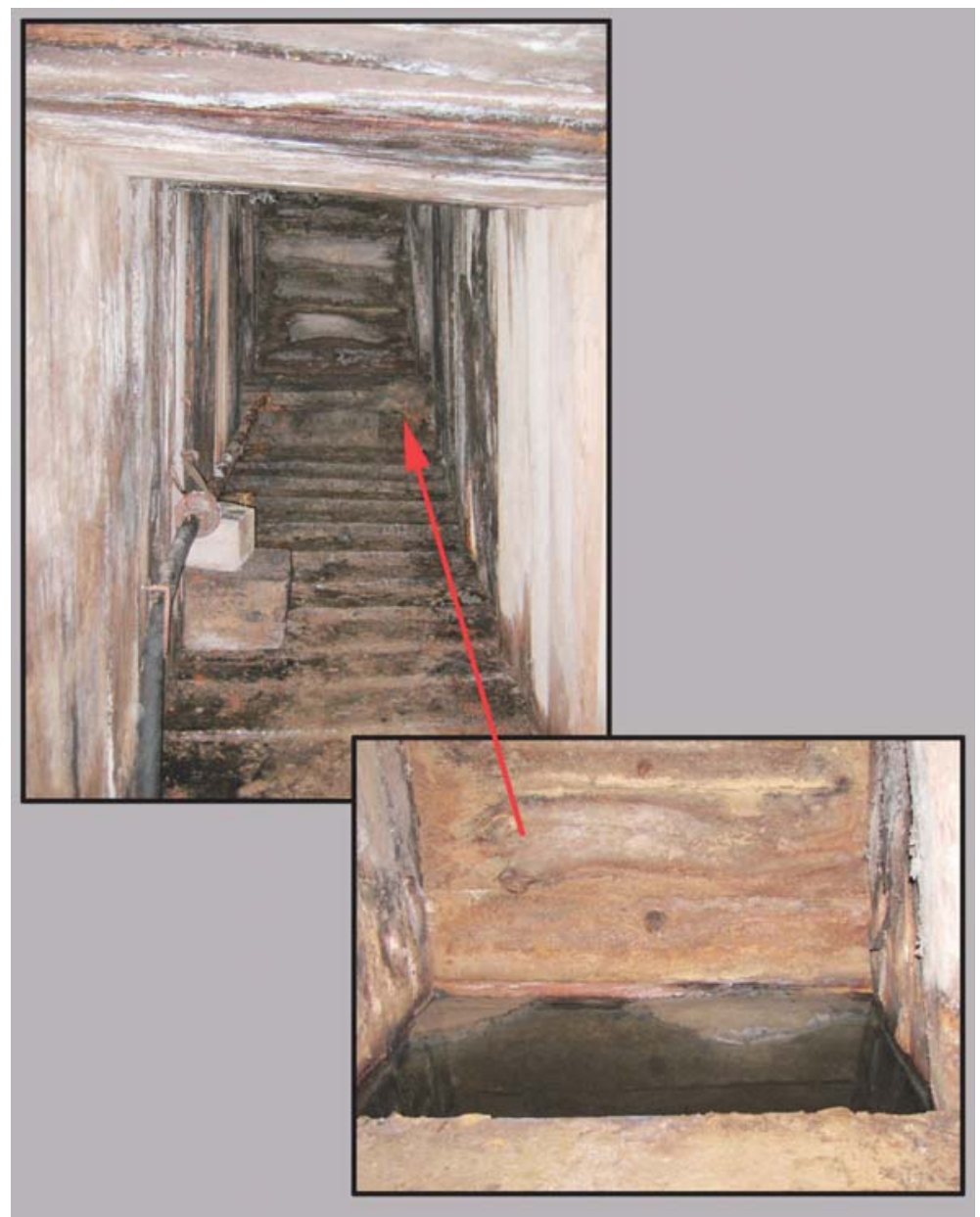

Fig. 5. Czoło chodnika Taras Wodny Gór Wschodnich dolny (fot. J. Przybyło 2010)

Fig. 5. The working head of Taras Wodny Gór Wschodnich lower (phot. J. Przybyło 2010) 


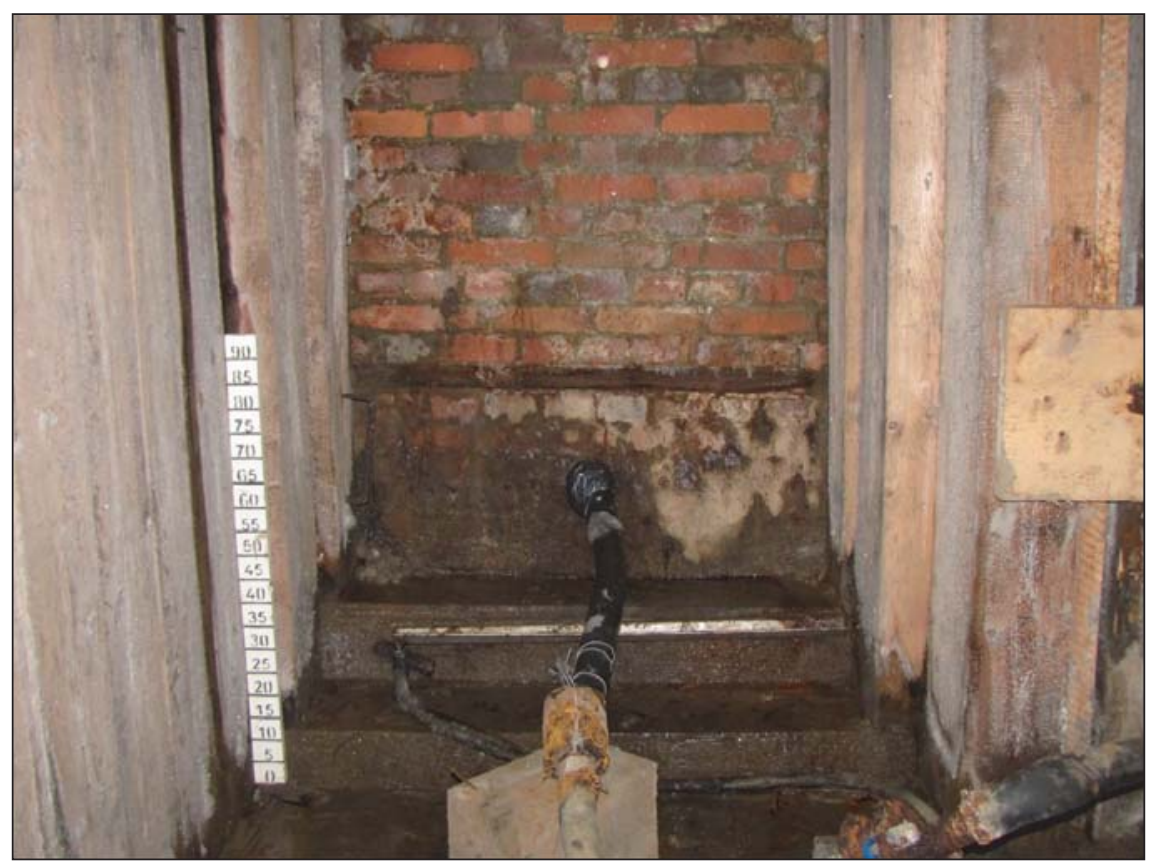

Fig. 6. Czoło chodnika Taras Wodny Gór Wschodnich górny (fot. J. Przybyło 2010)

Fig. 6. The working head of Taras Wodny Gór Wschodnich upper (phot. J. Przybyło 2010)

Dokumentacja dotycząca sposobu ujęcia wycieku oraz wielkości dopływu nie jest kompletna. Pierwsza informacja o wielkości dopływu $\left(2.5 \mathrm{dm}^{3} / \mathrm{min}\right)$ oraz zawartości $\mathrm{NaCl}$ w dopływie $\left(10 \mathrm{~g} / \mathrm{dm}^{3}\right)$ pochodzi z 1935 roku (Korytowski 1935).

Następne dane na temat wielkości dopływu oraz jego nasolenia znajdują się w rejestrze Dzikie dopływy w Kopalni w Wieliczce 1943-1960, gdzie wyciek występuje pod nazwą „Taras östlich”, lecz nie ma ich ciągłości. W niektórych okresach pomiary prowadzone były sporadycznie raz na rok, ale i są takie okresy, kiedy prawdopodobnie w ogóle ich nie wykonywano. W materiałach archiwalnych działu geologicznego brakuje pomiarów z lat 1952-1955, z roku 1958 oraz z lat 1965-1967. Do roku 1967 pomiary wykonywane były tylko w chodniku górnym. W latach 1967-1982 wyciek w chodniku dolnym oznaczony był numerem WI-42 (obecnie WI-36), a w chodniku górnym wyciek zarejestrowany był jako WI-40 i WI-41 (obecnie WI-37). Od 1969 roku pomiary wielkości dopływu prowadzone są systematycznie zarówno do chodnika dolnego, jak i górnego, lecz i w tym okresie w latach 1988-1994 występuje luka w pomiarach wielkości dopływu do WI-37, nie prowadzono ich z uwagi na zawałowy stan chodnika Taras Wodny Gór Wschodnich górny. Do analizy wielkości dopływu do rejonu Taras Wodny Gór Wschodnich przyjęto od 1969 roku sumę dopływu WI-36 i WI-37 (Dzikie dopływy w kopalni w Wieliczce 1943-1960, Kanach 1976, Rejestr wycieków kopalnianych 1969-2011) (Fig. 7). 


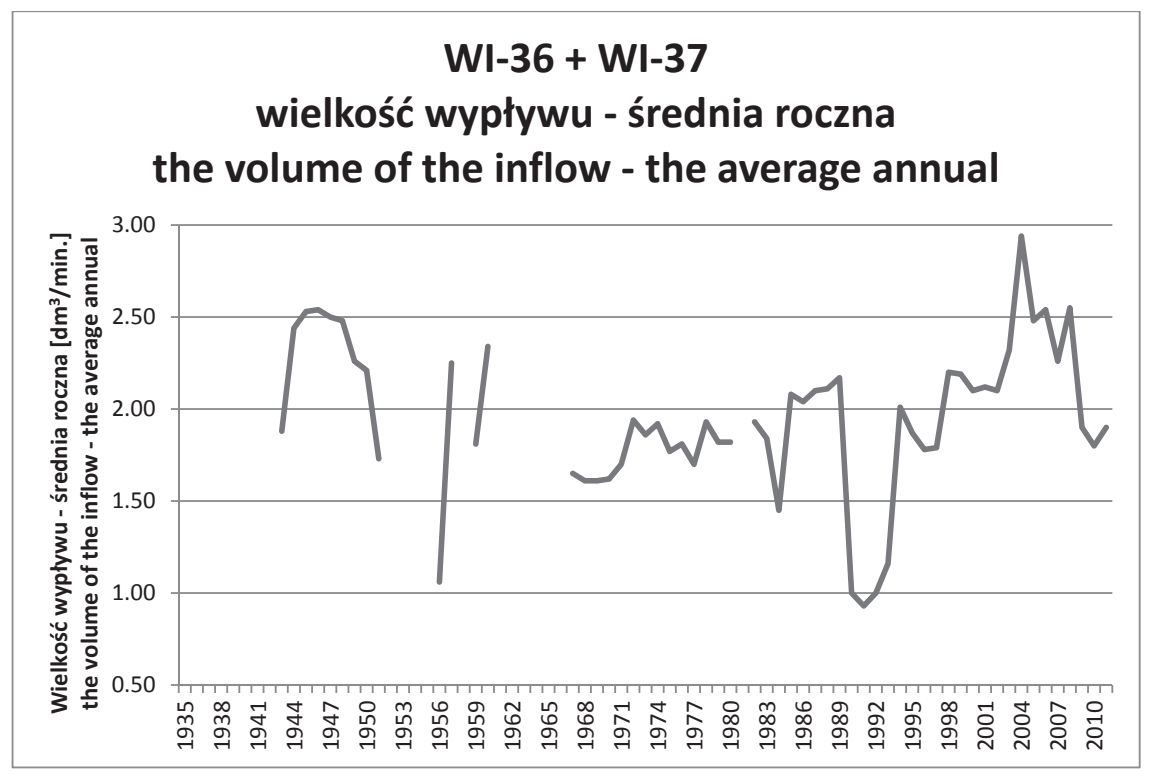

Fig. 7. Wielkość dopływu do rejonu Taras Wodny Gór Wschodnich

Fig. 7. The volume of the inflow to the area Taras Wodny Gór Wschodnich

Kilkudziesięcioletnie obserwacje wycieku pokazują, że wielkość dopływu utrzymuje się mniej więcej na jednakowym poziomie, tj. w granicach $0.93-2.94 \mathrm{dm} / \mathrm{min}$, przy czym minimalna wartość dotyczy okresu, kiedy nie było dojścia do wycieku WI-37, zaś maksymalna występuje po zakończeniu prac związanych z poprawą ujęć w chodnikach górnym i dolnym. Również zawartość $\mathrm{NaCl}$ w dopływie nie przekracza kilku gramów na decymetr sześcienny (Rejestr wycieków...).

Wahania wielkości dopływu do rejonu Taras Wodny Gór Wschodnich spowodowane są niecałkowitym ujęciem dopływu. Istnieją bowiem przecieki poza ujęcia w niższe partie górotworu, do pochylni prowadzącej do szybika komory Śmierdząca na poziomie IIn. Wykazały to przeprowadzone w dniach 03-27.06.1991 r. badania znacznikowe.

Znacznik (uranina) został zadany w chodniku Taras Wodny Wschodni przy wlocie do chodnika dolnego, gdzie wówczas występowało rząpie, w którym zbierała się woda przeciekająca przez drewniany próg zabudowany przed tamą w czole chodnika Taras Wodny dolny. Znacznik najpierw przemieścił się do znacznych rozmiarów kawerny znajdującej się ok. $40 \mathrm{~m}$ na W od rząpia (miejsca zadania znacznika) przy północnym ociosie podłużni Taras wypełnionej nasyconą solanką.

Obserwacje prowadzono w czterech punktach, w przypadku których podejrzewano możliwość dopływu z chodnika Taras Wodny Gór Wschodnich. Były to: WIV-15 - wyciek w spągu podsadzonej obecnie komory Seeling, WIII-20 - wyciek ze stropu komory Wessel, WIII-\#Lois wyciek z szybu Lois oraz WIIn-18 - wyciek ze stropu pochylni do szybika Śmierdząca. 
Tylko w próbach pobranych z wycieku WIIn-18 stwierdzono obecność znacznika $\mathrm{z}$ dwoma maksimami w różnym czasie, co wskazywało na co najmniej dwie drogi przepływu (Zuber et al. 1992).

Wycieki w rejonie wyrobisk Taras Wodny Gór Wschodnich mają długą historię obserwacji izotopowych (od lat 70. XX w.). Składy izotopowe wód w wyciekach WI-36 i WI-37 wykazują znaczne zróżnicowanie spowodowane mieszaniem się wód różnego wieku oraz przypuszczalnie nieznacznym odparowaniem.

Do wycieku WI-36 dopływała początkowo woda z wczesnego holocenu, niemająca bezpośredniego zasilania obecnymi wodami opadowymi, a następnie w dopływie pojawiła się mała domieszka współczesnej wody infiltracyjnej pochodzącej z opadów po rozpoczęciu prób termojądrowych, tj. po roku 1952. Od połowy lat 90. XX w. dopływa do wycieku w chodniku dolnym woda o ustabilizowanym udziale starszej wody holoceńskiej, o średnim czasie dopływu blisko 280 lat (na pewno dłuższym niż 55 lat), zmieszanej z wodą współczesną zasilaną opadami po 1952 roku (Zuber et.al. 2004, 2005, 2006, 2007, Różański et al. 2011) (Tab. 1).

\section{Tabela (Table) 1}

Wyniki analiz składu izotopowego i stężenia trytu w próbach wód pobranych z wycieku WI-36

Results of analyses of the isotopic composition and concentration of tritium in the water samples taken from the inflow WI-36

\begin{tabular}{|c|c|c|c|}
\hline \multirow{2}{*}{$\begin{array}{c}\text { Data pobrania próby } \\
\text { Date of sampling }\end{array}$} & $\delta^{18} \mathrm{O}$ & $\delta \mathrm{D}$ & $\begin{array}{c}\text { Tryt } \\
\text { Tritium }\end{array}$ \\
\cline { 2 - 4 } & {$\left[\%_{\text {SMow }}\right]$} & {$\left[\%_{\text {SMOw }}\right]$} & T.U. \\
\hline 16.03 .1974 & -10.20 & - & $2.0 \pm 2.0$ \\
\hline 16.11 .1974 & -9.50 & -68.0 & $0 \pm 2$ \\
\hline 20.09 .1985 & -9.70 & -67.0 & $5.7 \pm 1.5$ \\
\hline 18.05 .1987 & -9.80 & - & $4.3 \pm 1.0$ \\
\hline 15.12 .1993 & -9.60 & -69.0 & $5.0 \pm 0.5$ \\
\hline 20.09 .1995 & -9.60 & -69.0 & $4.8 \pm 0.5$ \\
\hline 16.10 .2003 & -9.66 & -69.6 & $4.5 \pm 0.4$ \\
\hline 30.09 .2005 & -9.57 & -67.7 & $4.6 \pm 0.4$ \\
\hline 09.10 .2006 & -9.79 & -68.7 & $4.0 \pm 0.4$ \\
\hline 10.10 .2007 & -977 & -67.2 & $3.4 \pm 0.4$ \\
\hline 01.09 .2011 & -9.74 & -67.9 & $3.4 \pm 0.4$ \\
\hline
\end{tabular}

T.U. - Tritium Unit. 
Badania składu izotopowego wody dopływającej do chodnika górnego (WI-37) wskazują na obecność początkowo starej wody holoceńskiej z niewielką zawartością trytu. Od roku 1995 następuje gwałtowny wzrost stężenia trytu, co spowodowane jest większym udziałem współczesnych wód opadowych o średnim czasie dopływu wynoszącym kilkanaście lat.

Gwałtowny wzrost stężenia trytu w latach 90. XX w. może świadczyć o przebiciu się nowej drogi przepływu z wodą dużo młodszą. Mieszany charakter wód wycieku WI-37 potwierdzają także stosunkowo niskie stężenia ${ }^{14} \mathrm{C}$, wskazujące, że jego obecność jest głównie wynikiem dopływu wody współczesnej (Zuber et. al. 2004, 2005, 2006, 2007, Różański et al. 2011) (Tab. 2).

\section{Tabela (Table) 2}

Wyniki analiz składu izotopowego i stężenia trytu oraz ${ }^{14} \mathrm{C} \mathrm{w}$ próbach wód pobranych z wycieku WI-37

Results of analyses of the isotopic composition, concentration of tritium and ${ }^{14} \mathrm{C}$ in the water samples water taken from the inflow WI-37

\begin{tabular}{|c|c|c|c|c|c|}
\hline Data pobrania próby & $\delta^{18} \mathrm{O}$ & $\delta \mathrm{D}$ & $\delta^{13} \mathrm{C}$ & $\begin{array}{c}\text { Tryt } \\
\text { Tritium }\end{array}$ & ${ }^{14} \mathrm{C}$ \\
\hline & {$\left[\% o_{\text {SMOW }}\right]$} & {$\left[\% o_{\text {SMOW }}\right]$} & {$\left[\% o_{\mathrm{PDB}}\right]$} & T.U. & pmc \\
\hline 28.10 .1980 & -9.50 & -67.5 & -16 & $5.2 \pm 1.5$ & $28.5 \pm 1.0$ \\
\hline 08.04 .1983 & -9.60 & -68.5 & - & $5.4 \pm 1.5$ & - \\
\hline 20.07 .1984 & -9.60 & -68.0 & - & $3.4 \pm 1.5$ & - \\
\hline 20.09 .1995 & -9.90 & -71.0 & - & $23.1 \pm 1.1$ & - \\
\hline 16.10 .2003 & -9.91 & -68.0 & - & $13.0 \pm 0.7$ & - \\
\hline 30.09 .2005 & -9.93 & $\begin{array}{l}-68.8 \\
-68.9\end{array}$ & - & $12.1 \pm 0.7$ & - \\
\hline 09.10 .2006 & $\begin{array}{c}-9.91 \\
-10.03\end{array}$ & -70.0 & - & $11.6 \pm 0.6$ & - \\
\hline 10.10 .2007 & -9.88 & -70.7 & - & $10.2 \pm 0.6$ & - \\
\hline 01.09.2011 & $\begin{array}{l}-9.72 \\
-9.67\end{array}$ & $\begin{array}{l}-68.1 \\
-68.6\end{array}$ & - & $7.4 \pm 0.5$ & - \\
\hline
\end{tabular}

T.U. - Tritium Unit, pme - percent modern carbon.

W roku 2011 wykonana została również analiza izotopowa wycieku WIIn-18. Skład izotopowy wody jest typowy dla wód holoceńskich, a małe stężenie trytu wskazuje na niewielki dopływ wód zasilanych po 1952 roku (Różański et al. 2011) (Tab. 3). 


\section{Tabela (Table) 3}

Wyniki analiz składu izotopowego i stężenia trytu w próbach wód pobranych z wycieku WIIn-18

Results of analyses of the isotopic composition and concentration of tritium in the water samples taken from the inflow WIIn-18

\begin{tabular}{|c|c|c|c|c|}
\hline \multirow{2}{*}{$\begin{array}{c}\text { Data pobrania próby } \\
\text { Date of sampling }\end{array}$} & $\begin{array}{c}\text { Numer wycieku } \\
\text { Number of inflow }\end{array}$ & $\delta^{18} \mathrm{O}$ & $\delta \mathrm{D}$ & $\begin{array}{c}\text { Tryt } \\
\text { Tritium }\end{array}$ \\
\cline { 3 - 5 } & WIIn-18 & -9.96 & -69.5 & T.U. \\
\hline 01.09 .2011 & {$\left[\%\right.$ osMow $\left.^{2}\right]$} & -69.4 & $1.4 \pm 0.4$ \\
\hline
\end{tabular}

T.U. - Tritium Unit.

Szczegółowe analizy chemiczne przeprowadzone w roku 2010 (Szczepańska-Plewa 2010) wykazały różnice w składzie i własnościach fizykochemicznych wód wycieków WI-36 i WI-37 (Tab. 4). Wody w obu wyciekach określono jako wody słonawe, o odczynie słabo zasadowym (Pazdro \& Kozerski 1990). Wyciek WI-36 charakteryzuje się jednak dużo wyższą mineralizacją oraz niższą twardością wód (wody bardzo miękkie wg Pazdro \& Kozerskiego 1990) w porównaniu z WI-37. Stosując klasyfikację Altowskiego-Szwieca, określono typ wody w wycieku WI-36 jako Na-Cl- $\mathrm{HCO}_{3}$ (woda sodowo-chlorkowo-wodorowęglanowa), natomiast typ wody w wycieku WI-37 jako $\mathrm{Na}-\mathrm{HCO}_{3}-\mathrm{Cl}_{-} \mathrm{SO}_{4}$ (woda sodowo-wodorowęglanowo-chlorkowo-siarczanowa).

\section{Tabela (Table) 4}

Wyniki analiz składu chemicznego wód z wycieków WI-36 i WI-37

Results of analyses of the chemical composition in the water samples from the leakage WI-36 and WI-37

\begin{tabular}{|c|c|c|c|}
\hline \multirow{2}{*}{$\begin{array}{c}\text { Chemizm } \\
\text { Chemistry }\end{array}$} & $\begin{array}{c}\text { Jednostka } \\
\text { Unit }\end{array}$ & WI-36 & WI-37 \\
\cline { 3 - 4 } & {$[-]$} & 22.07 .2010 & 22.07 .2010 \\
\hline $\mathrm{pH}$ & {$[\mathrm{mV}]$} & 8.44 & 7.66 \\
\hline $\mathrm{Eh}$ & {$[\mathrm{mS} / \mathrm{cm}]$} & 235 & 228 \\
\hline $\mathrm{EC}$ & {$\left[\mathrm{mg} / \mathrm{dm}^{3}\right]$} & 5.61 & 1.837 \\
\hline $\begin{array}{c}\text { Mineralizacja } \\
\text { Mineralization }\end{array}$ & {$\left[\mathrm{mg} / \mathrm{dm}^{3}\right]$} & 3780.60 & 1423.00 \\
\hline $\mathrm{Na}^{+}$ & {$\left[\mathrm{mg} / \mathrm{dm}^{3}\right]$} & 1333.00 & 334.50 \\
\hline $\mathrm{K}^{+}$ & {$\left[\mathrm{mg} / \mathrm{dm}^{3}\right]$} & 8.51 & 7.98 \\
\hline $\mathrm{NH}_{4}{ }^{+}$ & & 0.19 & 0.55 \\
\hline
\end{tabular}


Tabela (Table) $4 \mathrm{~cd}$. / cont.

\begin{tabular}{|c|c|c|c|}
\hline $\mathrm{Ca}^{2+}$ & {$\left[\mathrm{mg} / \mathrm{dm}^{3}\right]$} & 7.26 & 58.13 \\
\hline $\mathrm{Mg}^{2+}$ & {$\left[\mathrm{mg} / \mathrm{dm}^{3}\right]$} & 6.43 & 20.59 \\
\hline $\mathrm{Sr}^{2+}$ & {$\left[\mathrm{mg} / \mathrm{dm}^{3}\right]$} & $<0,2$ & 0.367 \\
\hline $\mathrm{Fe}^{2+}$ & {$\left[\mathrm{mg} / \mathrm{dm}^{3}\right]$} & 0.23 & 0.10 \\
\hline $\mathrm{Mn}^{2+}$ & {$\left[\mathrm{mg} / \mathrm{dm}^{3}\right]$} & 0.02 & 0.22 \\
\hline $\mathrm{Cl}^{-}$ & {$\left[\mathrm{mg} / \mathrm{dm}^{3}\right]$} & 1362.21 & 265.46 \\
\hline $\mathrm{Br}^{-}$ & {$\left[\mathrm{mg} / \mathrm{dm}^{3}\right]$} & $<1.5$ & $<1.5$ \\
\hline $\mathrm{J}^{-}$ & {$\left[\mathrm{mg} / \mathrm{dm}^{3}\right]$} & 1.98 & $<0.5$ \\
\hline $\mathrm{SO}_{4}{ }^{2-}$ & {$\left[\mathrm{mg} / \mathrm{dm}^{3}\right]$} & 248.00 & 201.70 \\
\hline $\mathrm{HCO}_{3}{ }^{2-}$ & {$\left[\mathrm{mg} / \mathrm{dm}^{3}\right]$} & 810.51 & 530.90 \\
\hline $\mathrm{NO}_{2}{ }^{-}$ & {$\left[\mathrm{mg} / \mathrm{dm}^{3}\right]$} & 0.20 & 0.09 \\
\hline $\mathrm{NO}_{3}{ }^{-}$ & {$\left[\mathrm{mg} / \mathrm{dm}^{3}\right]$} & $<0.4$ & $<0.4$ \\
\hline
\end{tabular}

Różnice w charakterze dopływów do chodników Taras Wodny Gór Wschodnich dolny i górny świadczą o zasilaniu z różnych systemów wodonośnych, jak również różnych drogach ich przepływów. Zwłaszcza nagły wzrost udziału współczesnej wody opadowej w dopływie do WI-37 oraz skrócenie czasu przepływu świadczą o otworzeniu się nowej drogi przepływu.

Niezbędna zatem staje się przebudowa chodników i dokładne ujęcie wycieków, tak aby można było odbierać je w całości i dokładnie rejestrować zmiany wielkości dopływów. Takie działania są konieczne również dla wyeliminowania przecieków poza ujęcia, a co za tym idzie - ługowania górotworu solnego na drodze przepływu w niższe rejony kopalni, co spowoduje poprawę jego stateczności.

Uzasadnione jest też wykonanie otworu piezometrycznego położonego na północ od końcówek chodników, w których ujęte są dopływy. Otwór ten wykorzystywany będzie do monitorowania zmian położenia zwierciadła wody w utworach warstw chodenickich oraz zmian parametrów fizykochemicznych tej wody.

\section{LITERATURA}

Bilans wycieków K.S. Wieliczka - stan na 31.12.2011. Archiwum Działu Geologicznego Kopalni Soli Wieliczka.

d’Obyrn K. \&Przybyło J., 2010. Rozpoznanie geologiczne złoża soli kamiennej Wieliczka do 1945 roku. Przegląd Górniczy, 3-4, 110-121.

Dzikie dopływy w kopalni w Wieliczce 1943-1960. Archiwum Działu Geologicznego Kopalni Soli Wieliczka. 
Jaworski W., Kurowski P. \& Kurowski R., 1984. Charakterystyka zabytkowych wyrobisk kopalni soli w Wieliczce. W: Studia i materiały do dziejów żup solnych w Polsce, XIII, Muzeum Żup Krakowskich, Wieliczka, 17-105.

Kanach J., 1976. Dokumentacja hydrogeologiczna źródeł zagrożenia wodnego dla złoża soli $w$ Wieliczce $w$ aspekcie zabezpieczenia kopalni i likwidacji zbędnych wyrobisk. Archiwum Działu Geologicznego Kopalni Soli Wieliczka.

Kolasa K. \& Kubik K., 1983. Poeksploatacyjne zapadliska wielickie. W: Studia i materiały do dziejów żup solnych w Polsce, XII, Muzeum Żup Krakowskich, Wieliczka, 7-62.

Korytowski Z., 1935. Plany poziomów kopalni wielickiej z oznaczeniem miejsc dzikich dopływów wód do kopalni. Archiwum Działu Geologicznego Kopalni Soli Wieliczka.

Manterys A., 1980. Dokumentacja geologiczna złoża soli kamiennej Wieliczka. Archiwum Działu Geologicznego Kopalni Soli Wieliczka.

Pazdro Z. \& Kozerski B., 1990. Hydrogeologia ogólna. Wydawnictwa Geologiczne, Warszawa.

Rejestr wycieków kopalnianych 1969-2011. Archiwum Działu Geologicznego Kopalni Soli Wieliczka.

Różański K., Kuc T., Duliński M. \& Gorczyca Z., 2011. Badania izotopowe prób wód z wycieków w Kopalni Soli $w$ Wieliczce pobranych $w$ roku 2011 wraz z interpretacja wyników. Archiwum Działu Geologicznego Kopalni Soli Wieliczka.

Sękiewicz J., 1966. Zagrożenie wodne kopalni soli Wieliczka Aneks. Archiwum Działu Geologicznego Kopalni Soli Wieliczka.

Szczepańska-Plewa J., 2010. Sprawozdanie z badań solanek z wycieków kopalnianych. Archiwum Działu Geologicznego Kopalni Soli Wieliczka.

Zejszner L., 1843. Krótki opis historyczny, geologiczny i górniczy Wieliczki. Nakładem B. Behra.

Zimny J., 1985. Dokumentacja geologiczna otworu badawczego H-11 wykonanego w rejonie poprzeczni Röeschner w poziomie V na obszarze górniczym Kopalni Soli Wieliczka $w$ Wieliczce. Archiwum Działu Geologicznego Kopalni Soli Wieliczka.

Zuber A., Grabczak J. \& Śliwka I., 1992. Wyniki analiz izotopowych i znacznikowych w próbach wód z Kopalni Soli Wieliczka. Archiwum Działu Geologicznego Kopalni Soli Wieliczka.

Zuber A. \& Duliński M., 2004. Badania izotopowe wód kopalnianych Wieliczki wykonane w latach 1973-2004: Rezultaty i ich interpretacja. Archiwum Działu Geologicznego Kopalni Soli Wieliczka.

Zuber A., Duliński M. \& Kuc T., 2005. Badania izotopowe prób wód z wycieków w Kopalni Soli $w$ Wieliczce wraz ze wstępną interpretacją wyników. Archiwum Działu Geologicznego Kopalni Soli Wieliczka.

Zuber A., Różański K. \& Duliński M., 2006. Badania izotopowe prób wód z wycieków w Kopalni Soli w Wieliczce pobranych w roku 2006 wraz ze wstęnna interpretacja wyników. Archiwum Działu Geologicznego Kopalni Soli Wieliczka.

Zuber A., Różański K. Kuc T. \& Duliński M., 2007. Badania izotopowe prób wód z wycieków w Kopalni Soli w Wieliczce pobranych w roku 2007 wraz z interpretacja wyników. Archiwum Działu Geologicznego Kopalni Soli Wieliczka. 


\section{Summary}

The leaks marked as WI-36 and WI-37, located at Level I in the Taras Wodny Gór Wschodnich working are the example of water collection points in barren rocks, outside the deposit boundary, and they belong to the group of the most important water leaks from a salt mine owing to their low $\mathrm{NaCl}$ contents. They are also the oldest existing and controlled salt mine leaks.

Level I is the closest to the surface and it was executed mostly in the top block portion of the deposit. in the northern ends of the corridors of the Taras Wodny Gor Wschodnich, formations belonging to the Chodenice aquifers were uncovered (Fig. 1).

The problem of area dehydration appeared in 1622 when a fresh water leak was identified in the deposit border area. That was confirmed by the map drafted by Marcin German in 1638 on which the presently non-existing corridor was described as a "furnace from which fresh water is pouring" (Fig. 2).

The leaks are presently collected in two places, in the lower and upper corridors marked as WI-36 (Fig. 5) and WI-37 (Fig. 6). Centuries-long observations allow us to determine the influx of water as nearly constant, varying within ca. $1.5-2.5 \mathrm{dm}^{3} / \mathrm{min}$ (Fig. 7), with the $\mathrm{NaCl}$ content not exceeding several grams per cubic decimeter.

The variations of incoming water quantities arriving at the Taras Wodny Gór Wschodnich are caused by incomplete collection. There are some leaks outside the collection points permeating lower parts of the rock mass to the ramp leading to the winze of the Śmierdzaca chamber at Level IIn, as indicated by marking studies conducted in 1991 (Figs 3, 4).

Isotopic composition of water from leaks WI-36 and WI-37 indicated a considerable dumping of mixed water of various ages, with probable partial evaporation. Based on isotopic studies, stable influx of present-day and older Holocene water was found in leak WI-36, with the average flow period of nearly 280 years (Tab. 1). The isotopic composition of water from WI-37 also indicated a mixed nature of the flow, with a larger proportion of present-day rainwater and the average flow period of about a dozen of years (Tab. 2). However, brine was found in leak WIIn-18, with the isotopic composition being typical for Holocene waters. Low concentration of tritium indicated poor influx of water fed after 1952 (Tab. 3).

Chemical analyses conducted in 2010 indicated differences in the composition and physical and chemical properties of the waters from leaks WI-36 and WI-37. Waters from both leaks were determined to be salty, with limited alkaline reaction. Leak WI-36 was characterized by much higher mineralization and lower water hardness in comparison to WI-37 (Tab. 4).

The differences in the characteristics of water inlets to the Taras Wodny Gor Wschodnich upper and lower corridors indicated that the areas were fed from various aquifers, as well as by various routes. Long-term observations of leaks WI-36 and WI-37 indicated the necessity to remodel and seal the water collection points to eliminate salt rock leaching around the inlets, with rock stability assurance. 